\title{
Timothy syndrome
}

INSERM

\section{Source}

INSERM. (1999). Orphanet: an online rare disease and orphan drug data base. Timothy syndrome. ORPHA:65283

Timothy syndrome is a multi-system disorder characterized by cardiac, hand, facial and neurodevelopmental features that include QT prolong ation, webbed fing ers and toes, flattened nasal bridge, low-set ears, small upper jaw, thin upper lip, and characteristic features of autism or autistic spectrum disorders. 